\title{
Diarylethene-modified nucleotides for switching optical properties in DNA
}

\author{
Sebastian Barrois and Hans-Achim Wagenknecht ${ }^{*}$
}

\section{Full Research Paper}

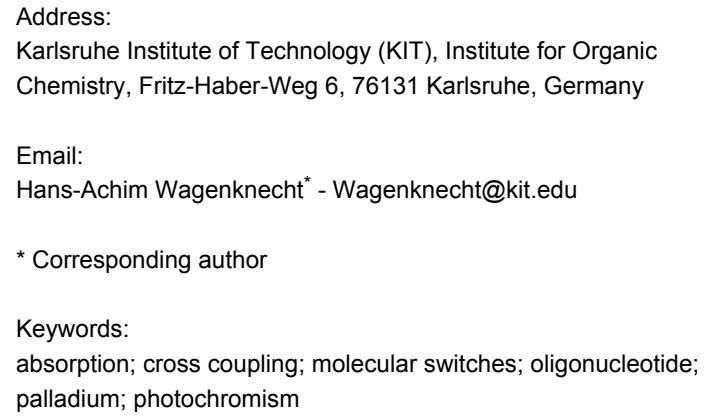

Beilstein J. Org. Chem. 2012, 8, 905-914. doi:10.3762/bjoc. 8.103

Received: 12 March 2012

Accepted: 09 May 2012

Published: 20 June 2012

This article is part of the Thematic Series "Molecular switches and cages".

Guest Editor: D. Trauner

(c) 2012 Barrois and Wagenknecht; licensee Beilstein-Institut. License and terms: see end of document.

\begin{abstract}
Diarylethenes were attached to the 5-position of 2'-deoxyuridine in order to yield three different photochromic nucleosides. All nucleosides were characterized with respect to their absorption and photochromic properties. Based on these results, the most promising photochromic DNA base modification was incorporated into representative oligonucleotides by using automated phosphoramidite chemistry. The switching of optical properties in DNA can be achieved selectively at $310 \mathrm{~nm}$ (forward) and $450 \mathrm{~nm}$ (backward); both wavelengths are outside the normal nucleic acid absorption range. Moreover, this nucleoside was proven to be photochemically stable and allows switching back and forth several times. These results open the way for the use of diarylethenes as photochromic compounds in DNA-based architectures.
\end{abstract}

\section{Introduction}

The well-defined photoinduced switching of the optical and electronic properties of molecular components represents an increasingly significant goal for the development of new photoreactive nanostructured architectures. Among those architectures, nucleic acids were proven to be an important scaffold for the precise arrangement of all kinds of chromophores inside or along the double helix [1-4]. Nucleic acids are synthesized by building blocks; in this bottom-up approach artificial functionalities, such as photoswitches, can be introduced synthetically by providing the corresponding artificial DNA building

block. Among the known and structurally diverse photochromic compounds [5-8], azobenzenes [9], spirobenzopyrans [10] and diarylethenes [11] represent the most promising candidates for introducing photoswitching functionality into biopolymers, and thereby for regulating biological activity $[12,13]$. Azobenzenes were designed and synthesized as artificial photoswitchable components in nucleic acids and are suitable for the control of a variety of different biological functions. The photoinduced cis-trans isomerization of azobenzene nucleosides can reversibly switch between the formation and dissociation of 
DNA duplexes [14-17], photoregulate DNA polymerase reaction [18], photocontrol DNA triplex formation [19], and drive photon-fueled DNA-based nanomachines [20,21].

Concerning the extent of structural change, the cis-trans isomerization of azobenzenes behaves much simpler than the ring opening of spiropyrans to merocyanines. In the latter case not only is a structural change observed but a large change in polarity is yielded additionally [10,22]. It is expected that the ring-closed spiropyran form of this molecular switch does not insert into the base stack due to its twisted structure, but the open merocyanine form could intercalate based on its planarity and polarity. This assumption was experimentally verified by synthetic spiropyrans as noncovalent DNA and RNA binders [23-25]. As expected, ground-state interactions between the noncovalently bound molecular switch and the DNA bases were detected in the case of the merocyanine form by CD spectroscopy, but not in the case of the spiropyran form. Attempts to attach spiropyrans covalently to DNA are rare [26,27] and include our recent approaches to incorporate synthetically the spiropyran chromophore [28], by either DNA building block 1 [29] or by DNA base modifications 2 and 3 [29,30], into oligonucleotides (Scheme 1). Although the spiropyran DNA building blocks 1 and $\mathbf{2}$ exhibit promising photochromic properties as

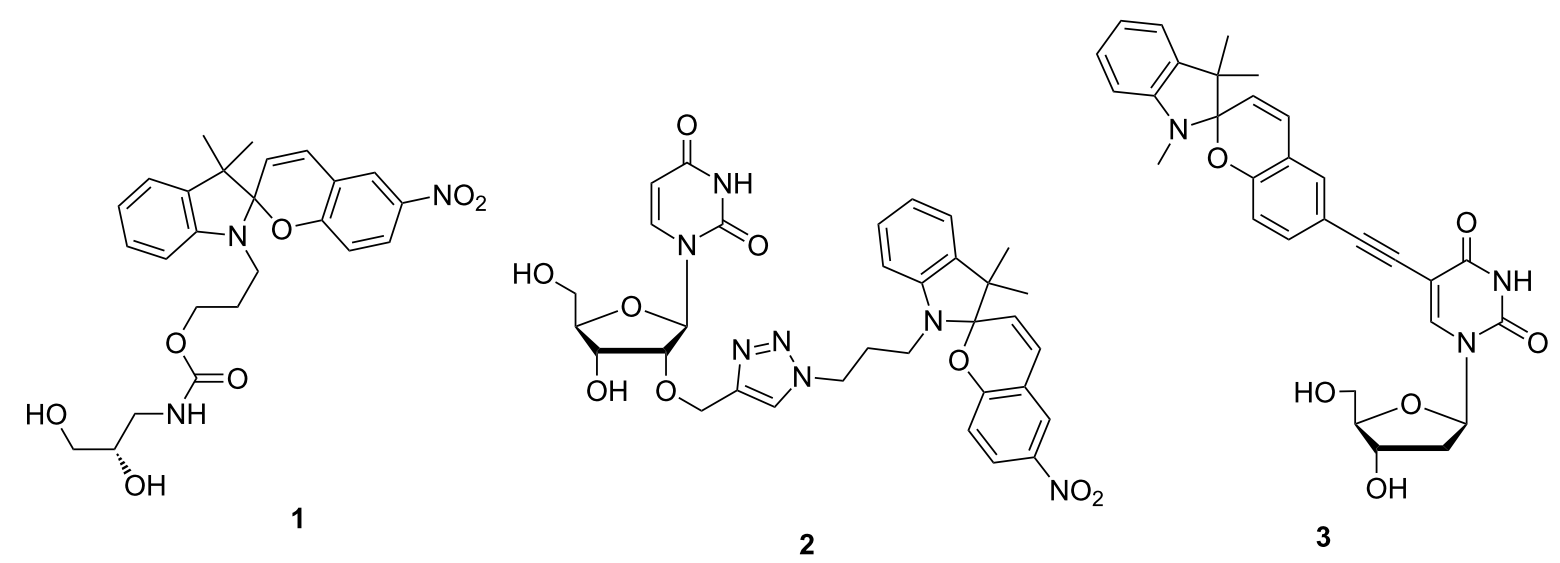<smiles></smiles><smiles>C=C</smiles><smiles></smiles>

4<smiles></smiles>

5<smiles>Cc1sc2ccc(C#Cc3cn(C)c(=O)[nH]c3=O)cc2c1C1=C(c2c(C)sc3ccc(C#Cc4cn(C)c(=O)[nH]c4=O)cc23)CCC1</smiles>

6

Scheme 1: Spiropyran as DNA base surrogate 1, DNA base modifications $\mathbf{2}$ and $\mathbf{3}$, and diarylethene-modified nucleosides 4-6. Photoswitching is representatively shown for nucleoside 4 . 
nucleosides, it is not worth pursuing this synthetic direction further for the following reasons [30]: (i) It is reported that spiropyrans decompose in aqueous buffer solutions [31], and (according to our experience) the DNA environment does not efficiently prevent this decomposition. (ii) Moreover, we found out that the spiropyran chromophore in the DNA environment loses its photoswitching abilities [29].

The second alternative, diarylethenes, have been applied for switching the binding affinities of proteins and peptides [32] but are still rather unexplored with respect to nucleic acids. The advantage of this type of photoswitch is that back reaction (reopening of the central ring) requires light and cannot be achieved in a thermally induced way. Diarylethenes have been applied in a noncovalent chiroptical photoswitchable DNA complex [33] and combined with 7-deazaadenosine to obtain a nucleosidic diarylethene switch [34]. Recently, we reported, very preliminarily, the preparation and optical properties of nucleoside 4 [30]. Herein, we give a full account and present the detailed synthesis of diarylethene-modified nucleosides 4,5 and 6 (Scheme 1), and the characterization of their photochromic behavior. It turned out to be most promising to continue the DNA work with the modified and photochromic nucleoside 4, which was, thus, incorporated into representative oligonucleotides by using automated phosphoramidite chemistry, and characterized with respect to its photochromism in DNA.

\section{Results and Discussion Design and synthesis of diarylethene-modi- fied 2'-deoxyuridines 4-6}

The typical way to tether fluorophores to oligonucleotides is to use an alkyl chain linker between the chromophore and DNA base as the point of attachment. The purpose of this conformationally flexible tether is to overcome problems in the enzymatic activity by DNA polymerases in the context of primerextension (PEX) or PCR studies [35-37]. However, the shortest possible linking of chromophores to oligonucleotides offers potentially interesting optical characteristics, among these being solvatochromism and red-shifted exciplex-type fluorescence [38]. Such absorption and fluorescence readouts are potentially suitable for DNA probing [39-41]. On the other hand, with respect to polymerase-assisted PEX and PCR experiments, an absolutely critical issue regarding the application of single $\mathrm{C}-\mathrm{C}$ bonds, or ethinyl or phenylene linkers is the question of whether the canonical base-recognition complementarity is effected by the chromophore modification $[42,43]$. Due to the strongest reactivity the 5-position of pyrimidines ( $\mathrm{U} / \mathrm{T}$ and $\mathrm{C}$ ) and the 8-position of purines (A and G) are preferred as chromophore modification sites. The assumption, that these points of attachment allow the chromophores to point into the major groove is only partially true, if at all. In particular, large and aromatic chromophores tend to insert into the base stack due to their hydrophobicity by changing the attached nucleoside from the natural anti- to the syn-conformation. The modification of the 8-position of purines clearly forces the nucleoside into the synconformation, which interferes with Watson-Crick base pairing. In the case of the pyrimidines the modification at position 5 should not significantly interfere with the preferred anti-conformation of the nucleosidic bond. Thus, the Watson-Crick base pairing of the corresponding modified oligonucleotides should be maintained. Over the past few years we have synthetically attached various chromophores, such as ethynylpyrenes $[44,45]$, BODIPY [46], ethynyl nile red $[47,48]$ and others, to 2 '-deoxyuridines for electron transfer studies and for fluorescent probes. To gain greater insight into the counterbase selectivity, we performed PEX experiments with a representative set of chromophore-modified oligonucleotides and found that the DNA-polymerase-catalyzed nucleotide incorporation opposite to attached chromophores at the 5-position of uridine follows Watson-Crick selectivity [49]. In the meantime, DNA polymerases have been evolved that have an increased reactivity for C5-modified deoxyribonucleotides [50]. Hence, it looked most reasonable to attach diarylethenes as photochromic compounds to the 5-position of 2'-deoxyuridine. The nucleoside 4 bears the bromine group, which was introduced initially for synthetic reasons. In the second nucleoside 5 the bromine was replaced by an ethynyl group. The third nucleoside $\mathbf{6}$ carries two 2'-deoxyuridine moieties and should principally allow connection of the two DNA double helices by the diarylethene linker as a covalent bridge between.

The preparation of all three nucleosides 4 [30], 5 and 6 (Scheme 2) is based on Sonogashira-type cross couplings as key steps [51] to attach the photoactive chromophore to the nucleoside. For the synthesis of the first nucleoside 4 (Scheme 2), commercially available 5-bromobenzothiazole (7) is deprotonated with LDA and methylated by methyl iodide in quantitative yield. The resulting 5-bromo-2-methylbenzothiazole (8) was converted in a double Friedel-Crafts-type acylation. Treatment with glutaryl chloride in the presence of $\mathrm{AlCl}_{3}$ connects two benzothiazoles 8 and provides 9 in 74\% yield. The double McMurry-type reaction, which is performed with $\mathrm{Zn}$ and $\mathrm{TiCl}_{4}$, forms the central cyclopentane ring of diarylethene 10. Subsequently, the ethynyl linker is attached to $\mathbf{1 0}$ by treatment with TMS-protected acetylene in a Pd-catalyzed cross-coupling reaction. Careful evaluation of this synthetic step revealed that the best yield (43\%) of the mono-ethinylated product 11 is obtained with 2 equiv of TMS-acetylene in the reaction mixture. The competitively formed doubly ethinylated diarylethene $\mathbf{1 2}$ is, of course, easier to obtain. In the latter case, a strong excess of TMS-acetylene (10 equiv) helps to increase the yield of prod- 


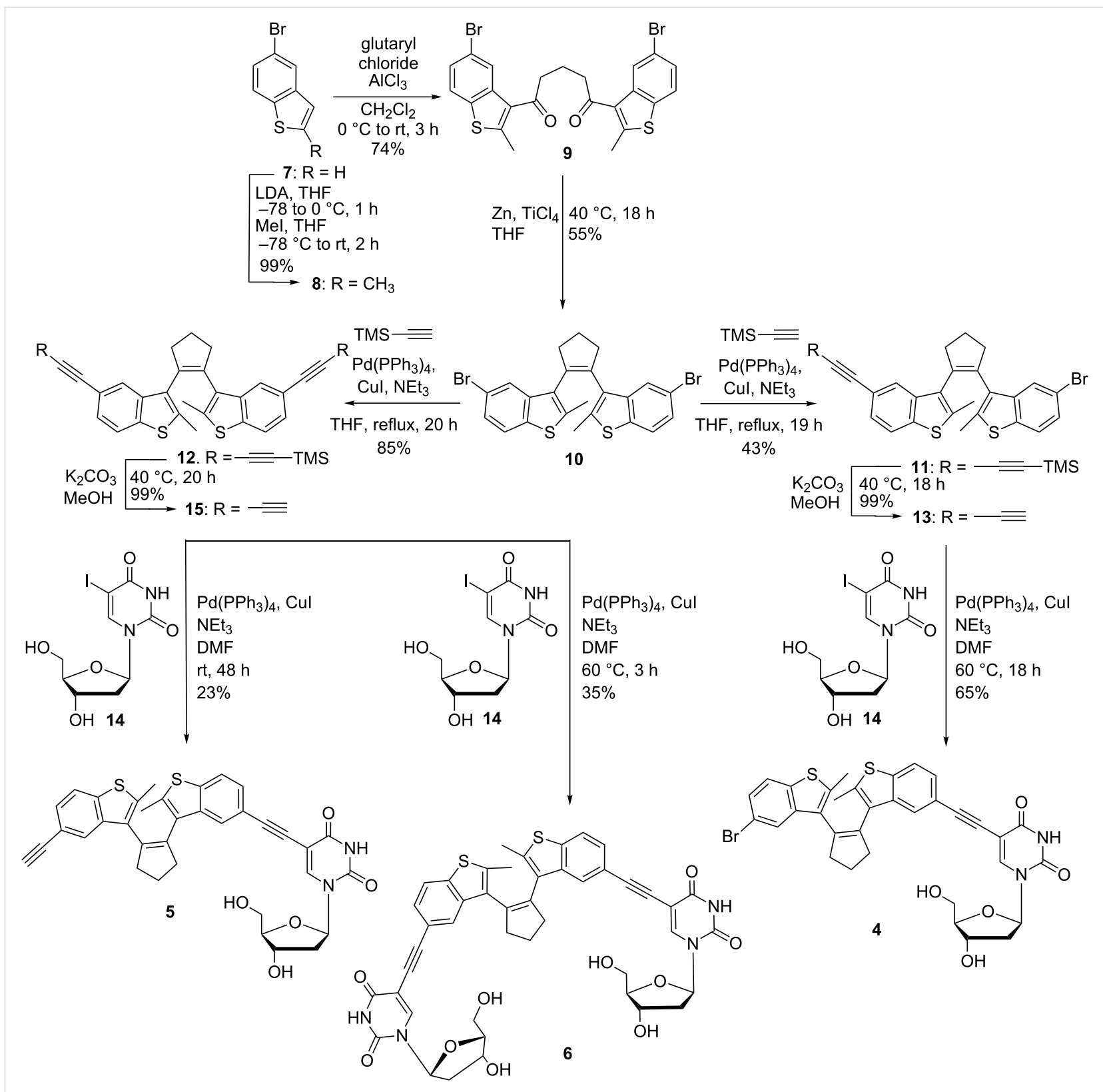

Scheme 2: Synthesis of diarylethene-modified 2'-deoxyuridines 4 [30], 5 and 6.

uct 12 to $85 \%$. The synthesis of the first diarylethene-modified nucleoside 4 then continues by cleavage of the TMS protecting group of $\mathbf{1 1}$ with $\mathrm{K}_{2} \mathrm{CO}_{3}$ in $\mathrm{MeOH}$. Finally, the synthesis is concluded by the Sonogashira-type coupling of diarylethene $\mathbf{1 3}$ to 5-iodo-2'-deoxyuridine (14) in 65\% yield.

For the second and third modified nucleosides $\mathbf{5}$ and $\mathbf{6}$, the last two synthetic steps are similar to those for nucleoside 4 . Deprotection of $\mathbf{1 2}$ gave the doubly ethinylated diarylethene $\mathbf{1 5}$ in quantitative yield. The subsequent Sonogashira coupling with $\mathbf{1 4}$ at $\mathrm{rt}$ gave the mono-nucleosidic product $\mathbf{5}$ in 23\% yield, and at $60{ }^{\circ} \mathrm{C}$ the di-nucleosidic product 6 in $35 \%$ yield.

\section{Photochromic properties of diarylethene- modified 2'-deoxyuridines 4-6}

The photochromic properties of the modified nucleosides 4-6 were characterized by UV-vis absorption spectroscopy at $\mathrm{rt}$. All irradiations for photoswitching of the nucleosides were performed by using a $75 \mathrm{~W}$ Xe arc lamp equipped with a monochromator for wavelength-selective excitation. The absorption of nucleoside 4 in the pure synthetic form (and presumably open form) shows absorption peaks in the UV range at $242 \mathrm{~nm}$ and $310 \mathrm{~nm}$ (Figure 1A). It is assumed that the band at $242 \mathrm{~nm}$ overlays with the absorption of the uracil moiety. Hence, the absorption side band at $310 \mathrm{~nm}$ should allow, at least in prin- 
A
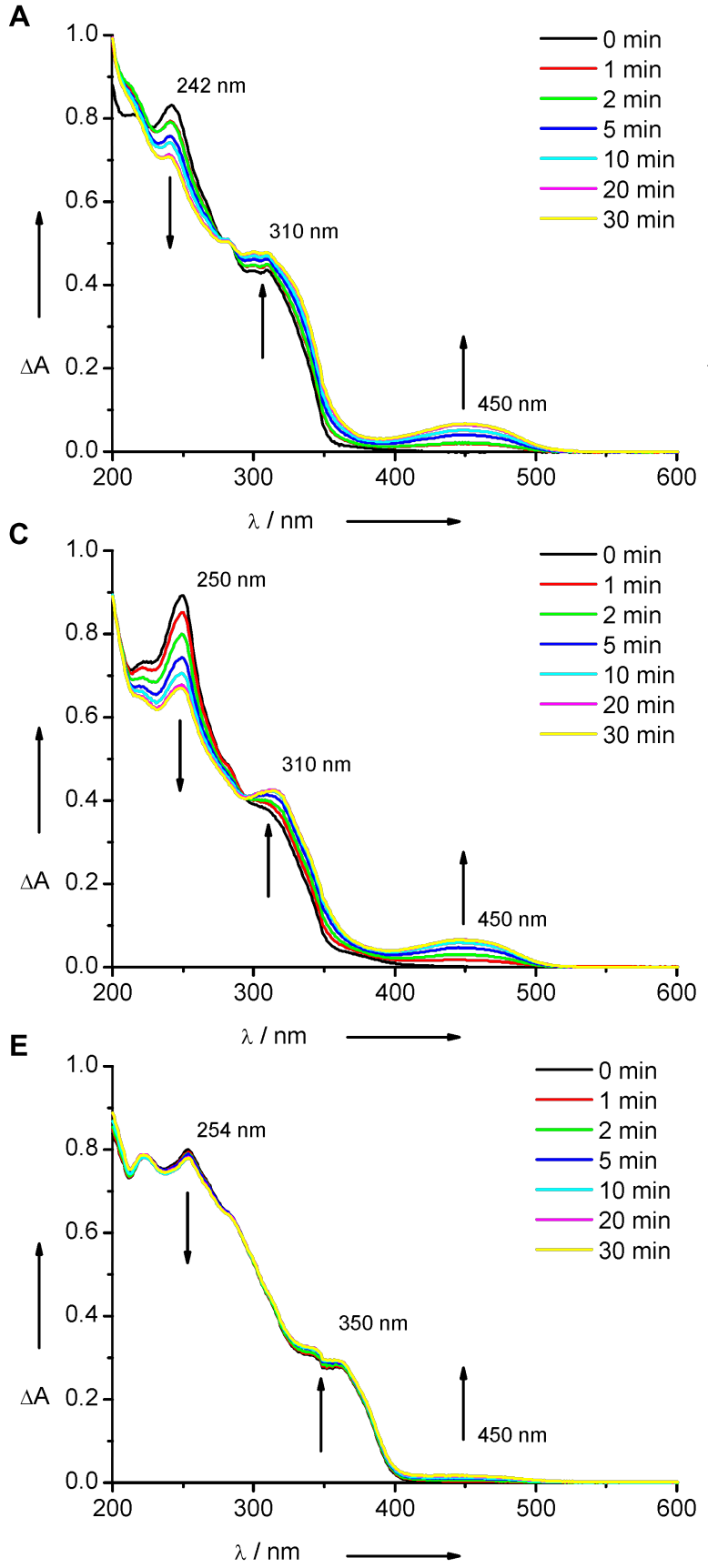

B
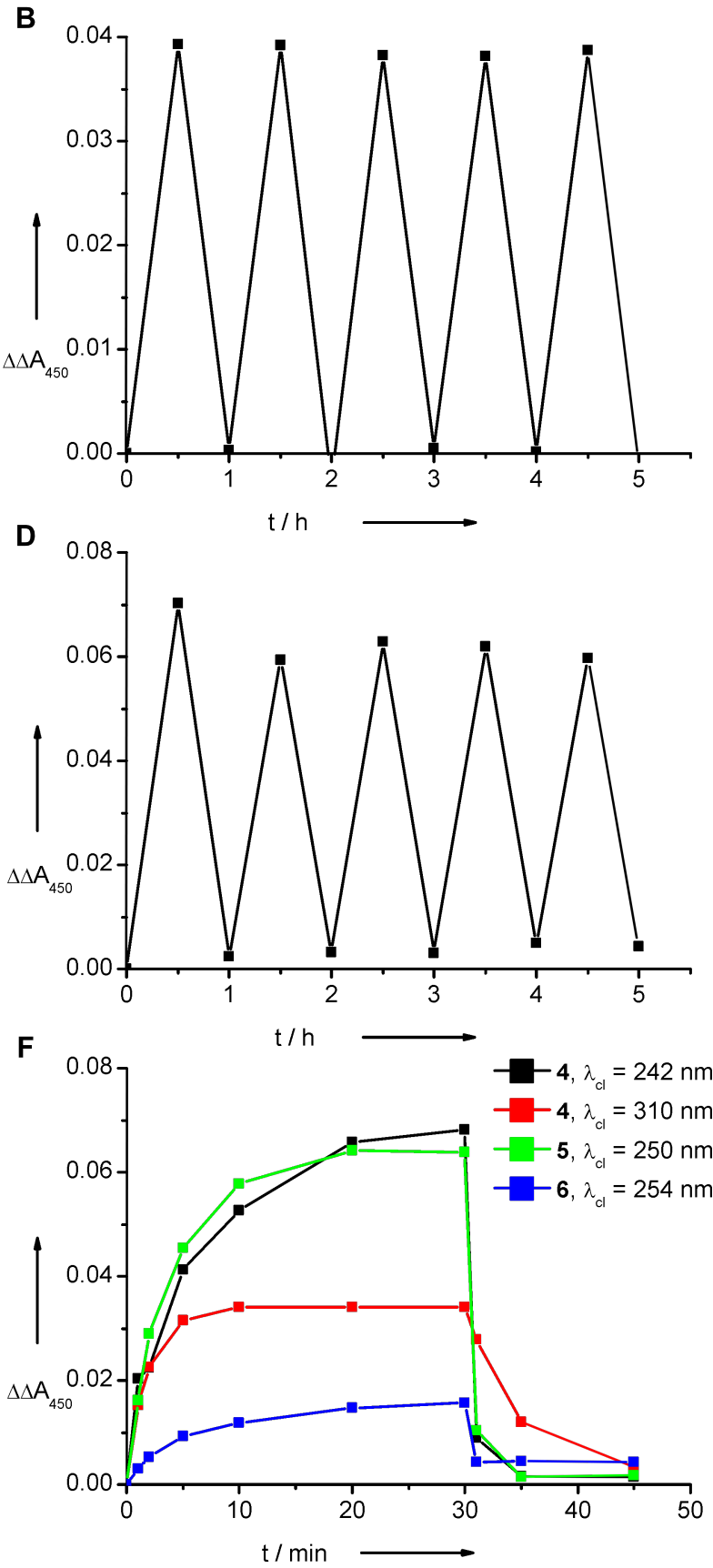

Figure 1: Photoswitching properties of nucleosides 4-6 (each $20 \mathrm{mM}$ in MeCN, rt). Top: Irradiation of 4 at $242 \mathrm{~nm}$ (A, left) and irradiation of 4 alternating at $242 \mathrm{~nm}$ and $450 \mathrm{~nm}$ (B, right). Middle: Irradiation of 5 at $250 \mathrm{~nm}$ (C, left) and irradiation of 5 alternating at $250 \mathrm{~nm}$ and $450 \mathrm{~nm}$ (D, right). Bottom: Irradiation of $\mathbf{6}$ at $254 \mathrm{~nm}$ (E, left) and plots of kinetic traces of absorption changes at $450 \mathrm{~nm}$ of all nucleosides 4-6 irradiated at the corresponding wavelength until $30 \mathrm{~min}$, then at $450 \mathrm{~nm}(\mathbf{F}$, right).

cipal, the selective excitation of the switch, outside the nucleic acid absorption range. Accordingly, the photoswitching of $\mathbf{4}$ was probed at 242 and $310 \mathrm{~nm}$. In fact, by irradiation at either wavelength the closed form of nucleoside $\mathbf{4}$ is formed with its characteristic band at $450 \mathrm{~nm}$ in the visible range. The color of the samples turns yellow. However, the differences in the absorption changes indicate that especially the contribution of the colored closed form of $\mathbf{4}$ in the photostationary state by excitation at $310 \mathrm{~nm}$ is less than at $242 \mathrm{~nm}$ (Figure 1F). Hence it can be concluded, that the band at $310 \mathrm{~nm}$ can be used indeed to 
excite selectively the diarylethene chromophore in nucleic acids, but the yield of the colored form is reduced. In all cases, the photostationary state was reached in $30 \mathrm{~min}$ since no additional changes were observed after that time. The absorption bands of the open and closed forms of $\mathbf{4}$ overlap in the UV range, which makes a detailed analysis of the photostationary state impossible. Irradiation of the sample at $450 \mathrm{~nm}$ reopens the diarylethene 4 within a few minutes. The absorption spectra of 4 during all irradiations show an isosbestic point at $275 \mathrm{~nm}$. As expected, the thermally induced opening of the closed chromophore in nucleoside $\mathbf{4}$ was never observed. The diarylethene nucleoside $\mathbf{4}$ stays chemically and photochemically stable and can be switched several times to the closed form, and back to the opened form (Figure 1B).

At first glance, the photochromic properties of the second nucleoside (5) are very similar to those of 4 (Figure 1C). However, a careful look at the absorption changes performed at $250 \mathrm{~nm}$ reveals that the isosbestic point between the closed and the opened form of nucleoside $\mathbf{5}$ has moved bathochromically from 275 to $300 \mathrm{~nm}$. Moreover, the closed form does not only show an increased absorption in the visible range at $450 \mathrm{~nm}$ but also a more significant contribution to the absorption in the UV range at $310 \mathrm{~nm}$. As a result, photoswitching from the opened form of 5 to the closed form at $310 \mathrm{~nm}$ cannot be performed in an efficient way. This result is in contrast to that for the first diarylethene-modified nucleoside $\mathbf{4}$ described above and limits the applicability of nucleoside $\mathbf{5}$ significantly as a photochromic switch in nucleic acids. The diarylethene $\mathbf{5}$ can be switched several times back and forth; however, the photochemical stability is slightly reduced compared to nucleoside 4 (Figure 1D).

A rather dramatic change of photochromic properties is observed upon comparison of nucleosides $\mathbf{4}$ and $\mathbf{5}$ with the third one (6). The synthetically obtained and thereby purely closed form of diarylethene 6 shows absorption at 254 and $350 \mathrm{~nm}$ (Figure 1E). Irradiation at $250 \mathrm{~nm}$ indeed shows the formation of the colored form at $450 \mathrm{~nm}$, but to a much smaller extent when compared with $\mathbf{4}$ or $\mathbf{5}$. Obviously, the conjugation of the terminal acetylene group of nucleoside $\mathbf{5}$ to a second 2'-deoxyuridine in $\mathbf{6}$ affects its photochromism significantly and reduces its photoswitching abilities.

\section{Synthesis and photochromic properties of DNA modified with diarylethene 4}

As mentioned in the introduction, in a bottom-up approach nucleic acids can be modified with artificial functionalities by providing the corresponding synthetic building blocks. Based on the previously described results regarding the photochromic properties of nucleosides 4 [30], 5 and $\mathbf{6}$ it appeared to be most promising to incorporate synthetically the nucleoside $\mathbf{4}$ into oligonucleotides. It is the only diarylethene that allows selective excitation at $310 \mathrm{~nm}$, outside of the absorption range of DNA. The preparation of the corresponding phosphoramidite $\mathbf{1 7}$ as an artificial DNA building block follows standard procedures (Scheme 3) [30]: Protection of the 5'-OH group of nucleoside 4 by DMT-chloride is followed by phosphitylation of the 3'-OH group of the intermediate $\mathbf{1 6}$ yielding phosphoramidite 17. By automated DNA synthesis on a solid phase we prepared a set of four oligonucleotides in order to report preliminarily the optical properties of $\mathbf{4}$ in DNA. The sequences were identical except for the base pairs that surround the position of nucleoside 4 . The oligonucleotides were purified by semipreparative HPLC, identified by mass spectrometry and quantified by their extinction coefficient at $260 \mathrm{~nm}$.

Irradiation of each of the four single-stranded oligonucleotides DNA1-DNA4 at $310 \mathrm{~nm}$ yields the characteristic absorption of the closed forms as small and broad bands at $\sim 450 \mathrm{~nm}$, and irradiation at this wavelength drives the reaction back toward the open form of the switch (representatively shown for DNA2 in Figure 2). The most remarkable result is that of DNA2 bearing two guanines in the direct vicinity of the diarylethene modification. Guanine is known to interfere with a variety of photophysical properties (mainly fluorescence) in DNA. It is important to mention here that guanine does not influence the photochromic properties of the diarylethene switch $\mathbf{4}$ as a DNA modification. In fact, the photoswitching behavior of $\mathbf{4}$ is maintained in all four different DNA environments. The sequence independent photochromic behavior represents an important result for the future application of this type of switch in DNA-based nanostructures. Representatively, we performed switching experiments with the double strand (ds) of the most critical candidate (DNA2). The kinetic behavior of the opening and closing of nucleoside $\mathbf{4}$ cannot be directly compared to dsDNA2 since the solvents in the two measurements are different. However, the photochromic switching is clearly observable in the absorption spectra (Figure 2A and 2B) and is very similar to that of the single strand. Double-stranded DNA2, with the diarylethene switch in the opened form, exhibits a melting temperature of $60.6^{\circ} \mathrm{C}$ and shows a high destabilization according to the unmodified double strand $\left(68.0^{\circ} \mathrm{C}\right)$. After irradiation at $310 \mathrm{~nm}$, the melting temperature decreases significantly to $56.8{ }^{\circ} \mathrm{C}$. According to the noncovalently bound diarylethene derivative as chiroptical switch published by Feringa and coworkers [33], the closed form is able to intercalate whereas the open form of the switch binds differently. This could potentially explain the difference in melting temperature for dsDNA2, since the intercalated closed form of the diarylethene interferes with stacking to the neighboring bases by the two methyl groups pointing up and down from the chromophore. 


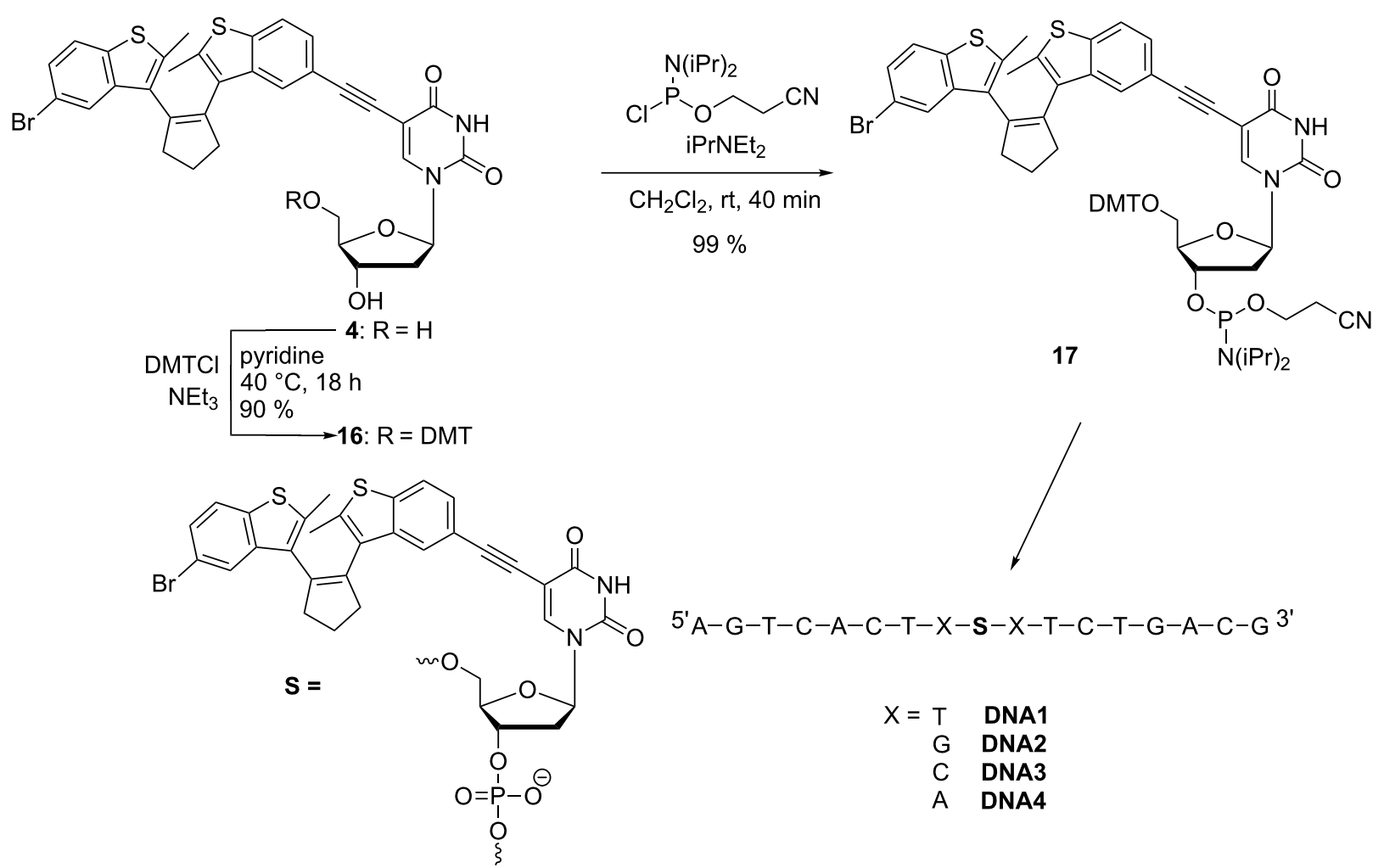

Scheme 3: Synthesis of DNA building block 17 [30] and sequences of diarylethene-modified DNA1-DNA4.
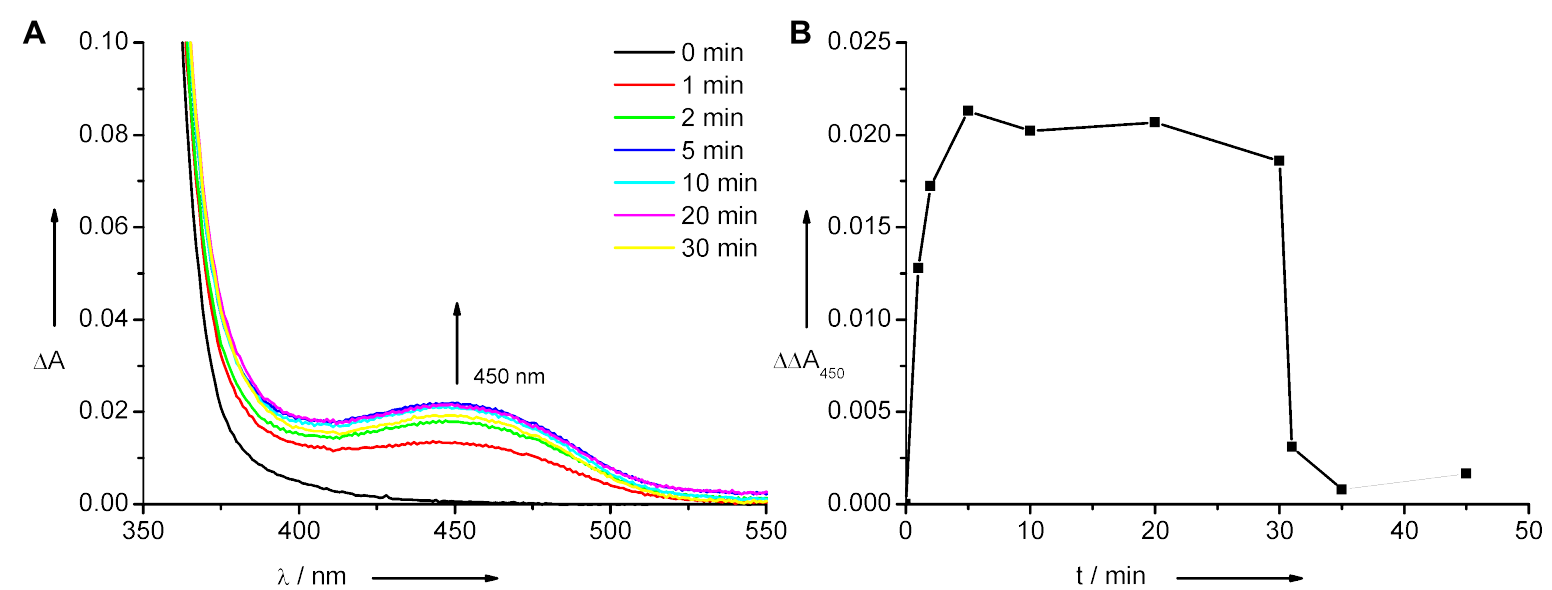

Figure 2: Irradiation of dsDNA2 at $310 \mathrm{~nm}$ (A, left) and plot of kinetic trace of absorption changes at $450 \mathrm{~nm}$ of dsDNA2 irradiated at $310 \mathrm{~nm}$ until $30 \mathrm{~min}$, then $450 \mathrm{~nm}(\mathrm{~B}$, right)

\section{Conclusion}

Three different diarylethene-modified 2'-deoxyuridines 4-6 were prepared by using Sonogashira-type cross couplings as key steps. The photochromic properties of the nucleosides were evaluated and revealed that only nucleoside 4 allows selective excitation at $310 \mathrm{~nm}$, outside the nucleic acid absorption window, to close the diarylethene chromophore. Switching back of the colored form of all three nucleosides 4-6 to the corres- ponding opened forms can be achieved by selective excitation at $450 \mathrm{~nm}$. Moreover, nucleoside 4 was proven to be photochemically stable and, hence, allows switching back and forth several times. Nucleoside 4 was incorporated into oligonucleotides by automated DNA synthesis. It is remarkable that the photochromic properties of $\mathbf{4}$ are maintained for the corresponding base modification in oligonucleotides and show sequence-independent switching behavior. Our results open the 
way for the use of diarylethenes as photochromic compounds in DNA-based architectures and represent one important step further for the design and synthesis of photoreactive and selfassembled nanostructures and materials based on nucleic acids.

\section{Experimental Materials and methods}

Chemicals were purchased from Sigma Aldrich, Fluka, ABCR, Alfa Aesar and Acros. Unmodified oligonucleotides were purchased from Metabion. TLC was performed on Merck silica gel $60 \mathrm{~F}_{254}$ coated aluminum foil. Flash chromatography was carried out with silica gel 60 from Aldrich $(60-73 \mu \mathrm{m})$. Spectroscopic measurements and the melting points were recorded on a Varian Cary 100 spectrometer in quartz-glass cuvettes. Irradiation experiments were performed with a $75 \mathrm{~W}$ Xe arc lamp equipped with a monochromator. The synthetic procedures for compounds 4, 8, 9, 10, 11, 13, 16 and 17 have been already described in [30].

Compound 12: 10 (617 mg, $1.19 \mathrm{mmol})$, trimethylsilylacetylene (1.68 mL, $11.90 \mathrm{mmol})$, dry $\mathrm{NEt}_{3}(0.39 \mathrm{~mL}, 4.76 \mathrm{mmol})$, $\mathrm{Pd}\left(\mathrm{PPh}_{3}\right)_{4}(550 \mathrm{mg}, 0.48 \mathrm{mmol})$ and $\mathrm{CuI}(91 \mathrm{mg}, 0.48 \mathrm{mmol})$ were dissolved in dry THF $(11 \mathrm{~mL})$ under argon. The mixture was degassed and heated under reflux for $20 \mathrm{~h}$. After cooling to $\mathrm{rt}$, the solvent was removed under reduced pressure. The residue was dried in vacuo and purified by flash chromatography on silica gel (hexanes-toluene 100:1) to yield $559 \mathrm{mg} 12(85 \%)$ as a white solid. $R_{\mathrm{f}} 0.20$ (hexanes); ${ }^{1} \mathrm{H}$ NMR $\left(300 \mathrm{MHz}, \mathrm{CDCl}_{3}\right) \delta$ 7.72 (s, 2H, H-Ar), 7.56 (d, $J=7.9 \mathrm{~Hz}, 2 \mathrm{H}, \mathrm{H}-\mathrm{Ar}), 7.30$ (d, $J=$ $6.9 \mathrm{~Hz}, 2 \mathrm{H}, \mathrm{H}-\mathrm{Ar}), 3.20-2.80\left(\mathrm{~m}, 4 \mathrm{H}, \mathrm{CH}_{2}\right), 2.31$ (p, $J=$ $\left.6.8 \mathrm{~Hz}, 2 \mathrm{H}, \mathrm{CH}_{2}\right), 1.99$ (s, 6H, $\left.\mathrm{CH}_{3}\right), 0.30$ (s, 18H, $\left.\mathrm{Si}\left(\mathrm{CH}_{3}\right)_{3}\right)$; ${ }^{13} \mathrm{C}$ NMR (75 MHz, $\left.\mathrm{CDCl}_{3}\right) \delta 139.3$ ( $\left.\mathrm{C}_{\text {quart. }}\right), 138.7$ ( $\left.\mathrm{C}_{\text {quart. }}\right)$, 137.5 ( $\left.\mathrm{C}_{\text {quart. }}\right), 137.1$ ( $\left.\mathrm{C}_{\text {quart. }}\right), 130.2$ ( $\left.\mathrm{C}_{\text {quart }}\right), 127.1$ ( $\left.\mathrm{C}_{\text {arom. }}\right)$, $126.1\left(\mathrm{C}_{\text {arom. }}\right), 121.9\left(\mathrm{C}_{\text {arom. }}\right), 118.7\left(\mathrm{C}_{\text {arom. }}\right), 106.0(\mathrm{C} \equiv \mathrm{C})$, $37.9\left(\mathrm{CH}_{2}\right), 29.9(\mathrm{C} \equiv \mathrm{C}), 24.3\left(\mathrm{CH}_{2}\right), 15.4\left(\mathrm{CH}_{3}\right), 0.3$ $\left(\mathrm{Si}\left(\mathrm{CH}_{3}\right)_{3}\right)$; EIMS (70 eV) $\mathrm{m} / z(\%): 552.2$ (8) $[\mathrm{M}]^{+}$; HRMS-ESI $(\mathrm{m} / \mathrm{z})$ : $[\mathrm{M}]^{+}$calcd for $\mathrm{C}_{33} \mathrm{H}_{36} \mathrm{~S}_{2} \mathrm{Si}_{2}, 552.1797$; found, 552.1794

Compound 15: 12 (408 mg, $0.74 \mathrm{mmol}$ ) was dissolved in dry $\mathrm{MeOH}\left(15 \mathrm{~mL}\right.$ ), and $\mathrm{K}_{2} \mathrm{CO}_{3}$ (408 mg, $2.95 \mathrm{mmol}$ ) was added. The reaction mixture was stirred for $20 \mathrm{~h}$ at $40{ }^{\circ} \mathrm{C}$. After cooling to rt, $\mathrm{MeOH}$ was removed under reduced pressure. The residue was dried in vacuo and purified by flash chromatography on silica gel (hexanes-toluene 10:1) yielding $299 \mathrm{mg} 15$ $(99 \%)$ as a white solid. $R_{\mathrm{f}} 0.41$ (hexanes-toluene 10:1); ${ }^{1} \mathrm{H}$ NMR (400 MHz, $\mathrm{CDCl}_{3}$ ) $\delta 7.75$ (s, 2H, H-Ar), 7.57 (s, 2H, $\mathrm{H}-\mathrm{Ar}$ ), 7.31 (s, 2H, H-Ar), 3.08 (s, 2H, C $\equiv \mathrm{CH}), 3.01-2.77$ (m, $4 \mathrm{H}, \mathrm{CH}_{2}$ ), 2.28 (p, J=7.3 Hz, 2H, $\left.\mathrm{CH}_{2}\right), 1.96$ (s, 6H, $\mathrm{CH}_{3}$ ); ${ }^{13} \mathrm{C}$ NMR (101 MHz, $\left.\mathrm{CDCl}_{3}\right) \delta 139.3\left(\mathrm{C}_{\text {quart. }}\right), 138.9\left(\mathrm{C}_{\text {quart. }}\right)$, $137.1\left(\mathrm{C}_{\text {quart }}\right), 130.0\left(\mathrm{C}_{\text {quart. }}\right), 128.5$ ( $\left.\mathrm{C}_{\text {quart }}\right), 126.8\left(\mathrm{C}_{\text {arom. }}\right)$,
$126.4\left(\mathrm{C}_{\text {arom. }}\right), 122.0\left(\mathrm{C}_{\text {arom. }}\right), 117.6\left(\mathrm{C}_{\text {arom. }}\right), 76.4(\mathrm{C} \equiv \mathrm{C}), 37.9$ $\left(\mathrm{CH}_{2}\right), 29.9(\mathrm{C} \equiv \mathrm{C}), 24.2\left(\mathrm{CH}_{2}\right), 15.2\left(\mathrm{CH}_{3}\right)$; EIMS $(70 \mathrm{eV}) \mathrm{m} / \mathrm{z}$ (\%): $408.1(48)[\mathrm{M}]^{+}$.

Compound 5: 15 (75 mg, $0.18 \mathrm{mmol}$ ), 5-iodo-2'-deoxyuridine (14, $65 \mathrm{mg}, 0.18 \mathrm{mmol})$, dry $\mathrm{NEt}_{3}(30 \mu \mathrm{L}, 0.37 \mathrm{mmol})$, $\mathrm{Pd}\left(\mathrm{PPh}_{3}\right)_{4}(42 \mathrm{mg}, 0.04 \mathrm{mmol})$ and $\mathrm{CuI}(7 \mathrm{mg}, 0.04 \mathrm{mmol})$ were dissolved in dry DMF $(7 \mathrm{~mL})$. The mixture was degassed and stirred for $48 \mathrm{~h}$ at $\mathrm{rt}$. The solvent was removed under reduced pressure and the residue was dried in vacuo and purified by flash chromatography on silica gel $\left(\mathrm{CH}_{2} \mathrm{Cl}_{2}-\mathrm{MeOH}\right.$ 10:1) yielding $27 \mathrm{mg} 5(23 \%)$ as a white solid. $R_{\mathrm{f}} 0.53$ $\left(\mathrm{CH}_{2} \mathrm{Cl}_{2}-\mathrm{MeOH} 5: 1\right) ;{ }^{1} \mathrm{H} \mathrm{NMR}\left(300 \mathrm{MHz}, \mathrm{CDCl}_{3}\right) \delta 8.01$ (s, $1 \mathrm{H}, \mathrm{NH}), 7.82(\mathrm{~s}, 1 \mathrm{H}, \mathrm{C}=\mathrm{CH}), 7.70(\mathrm{~s}, 2 \mathrm{H}, \mathrm{H}-\mathrm{Ar}), 7.55(\mathrm{~d}, J=$ $7.8 \mathrm{~Hz}, 2 \mathrm{H}, \mathrm{H}-\mathrm{Ar}), 7.36$ (s, 2H, H-Ar), 6.22 (t, $J=6.0 \mathrm{~Hz}, 1 \mathrm{H}$, 1 '-H), 4.62 (s, 1H, 3'-H), 4.16-4.02 (m, 1H, 4'-H), 4.00-3.85 (m, 2H, 5'-H), $3.08(\mathrm{~s}, 1 \mathrm{H}, \mathrm{C} \equiv \mathrm{CH}), 3.02-2.72\left(\mathrm{~m}, 4 \mathrm{H}, \mathrm{CH}_{2}\right)$, $2.40(\mathrm{~s}, 1 \mathrm{H}, 2$ '- $\mathrm{H}), 2.26\left(\mathrm{~s}, 2 \mathrm{H}, \mathrm{CH}_{2}\right), 2.05-1.79\left(\mathrm{~m}, 7 \mathrm{H}, \mathrm{CH}_{3}\right.$, ${ }^{2}$ - $\left.\mathrm{H}\right) ;{ }^{13} \mathrm{C} \mathrm{NMR}\left(75 \mathrm{MHz}, \mathrm{CDCl}_{3}\right) \delta 154.2,142.7,141.4$, $140.1,138.9,138.6,137.2,130.0,127.1,127.0,121.6,118.0$, $106.1,90.4,88.1,77.3,72.8,64.0,42.5,38.5,24.9,15.0$; MALDI-MS $m / z(\%): 633.6(5)[\mathrm{M}]^{+}$; HRMS-ESI $(\mathrm{m} / \mathrm{z})$ : [M + $\mathrm{H}]^{+}$calcd for $\mathrm{C}_{36} \mathrm{H}_{31} \mathrm{~N}_{2} \mathrm{O}_{5} \mathrm{~S}_{2}$, 635.1674; found, 635.1681.

Compound 6: 15 ( $81 \mathrm{mg}, 0.20 \mathrm{mmol})$, 5-iodo-2'-deoxyuridine (14, $140 \mathrm{mg}, 0.40 \mathrm{mmol})$, dry $\mathrm{NEt}_{3}(30 \mu \mathrm{L}, 0.40 \mathrm{mmol})$, $\mathrm{Pd}\left(\mathrm{PPh}_{3}\right)_{4}(46 \mathrm{mg}, 0.04 \mathrm{mmol})$ and $\mathrm{CuI}(8 \mathrm{mg}, 0.04 \mathrm{mmol})$ were dissolved in dry DMF $(7 \mathrm{~mL})$. The mixture was degassed and stirred for $3 \mathrm{~h}$ at $60{ }^{\circ} \mathrm{C}$. After cooling to rt, the solvent was removed under reduced pressure, and the residue was dried in vacuo and purified by flash chromatography on silica gel $\left(\mathrm{CH}_{2} \mathrm{Cl}_{2}-\mathrm{MeOH} 15: 1\right)$ to yield $60 \mathrm{mg} 6(35 \%)$ as a white solid. $R_{\mathrm{f}} 0.55\left(\mathrm{CH}_{2} \mathrm{Cl}_{2}-\mathrm{MeOH} 10: 1\right) ;{ }^{1} \mathrm{H}$ NMR (400 MHz, DMSO- $\left.d_{6}\right)$ $\delta 8.87(\mathrm{~s}, 1 \mathrm{H}, \mathrm{NH}), 8.38(\mathrm{~s}, 1 \mathrm{H}, \mathrm{NH}), 7.97(\mathrm{~s}, 2 \mathrm{H}, \mathrm{C}=\mathrm{CH}), 7.85$ (d, $J=9.3 \mathrm{~Hz}, 2 \mathrm{H}, \mathrm{H}-\mathrm{Ar}$ ), 7.80-7.52 (m, 4H, H-Ar), 6.31-6.02 (m, 2H, 1'-H), 5.31 (d, J=10.7 Hz, 2H, 3'-H), 5.24-5.08 (m, $\left.2 \mathrm{H}, 4^{\prime}-\mathrm{H}\right), 4.27\left(\mathrm{~s}, 2 \mathrm{H}, 5^{\prime}-\mathrm{H}\right), 3.94-3.83\left(\mathrm{~m}, 2 \mathrm{H}, 5^{\prime}-\mathrm{H}\right)$, 3.79-3.43 (m, 4H, $\left.\mathrm{CH}_{2}\right), 3.17-3.13\left(\mathrm{~m}, 2 \mathrm{H}, 2^{\prime}-\mathrm{H}\right), 3.00-2.67$ (m, $\left.10 \mathrm{H}, 2^{\prime}-\mathrm{H}, \mathrm{CH}_{2}, \mathrm{CH}_{3}\right) ;{ }^{13} \mathrm{C}$ NMR (101 MHz, DMSO-d $\left.d_{6}\right) \delta$ $161.4,153.9,149.4,137.5,136.2,130.3,130.0,129.6,122.8$, $120.1,117.9,117.6,106.9,99.5,99.2,98.3,88.2,87.6,84.8$, 70.1, 69.5, 60.9, 60.7, 45.6, 37.5, 29.0, 28.7, 23.4, 22.1, 15.0 . MS-FAB $m / z(\%): 883.4(25)[\mathrm{M}+\mathrm{Na}]^{+}$; HRMS-ESI $(\mathrm{m} / \mathrm{z})$ : $[\mathrm{M}+\mathrm{H}]^{+}$calcd for $\mathrm{C}_{45} \mathrm{H}_{41} \mathrm{~N}_{4} \mathrm{O}_{10} \mathrm{~S}_{2}, 861.2264$; found, 861.2282 .

DNA synthesis: Oligonucleotides were prepared with an Expedite 8909 Synthesizer from ABI by using standard phosphoramidite chemistry. Reagents and CPGs were purchased from $\mathrm{ABi}$ and Glen research. Modified oligonucleotides were synthesized by a modified protocol. The activator solution 
(0.45 M tetrazole in $\mathrm{MeCN}$ ) was pumped simultaneously with the building block 17 [30] and the coupling time was extended to $35 \mathrm{~min}$, with an intervening step after $17.5 \mathrm{~min}$ for washing and refreshing of the activator-17 solution. After coupling, the vial was washed with $\mathrm{MeCN}$. When the synthesis was complete the trityl-on oligonucleotides were treated with conc. $\mathrm{NH}_{4} \mathrm{OH}$ $\left(700 \mu \mathrm{L},>25 \%\right.$, trace select, Fluka) at $55{ }^{\circ} \mathrm{C}$ for $14 \mathrm{~h}$ for cleavage from the resin for deprotection. The oligonucleotides were purified by HPLC on a semipreparative RP-18 column (300 $\AA$, Supelco) by using $\mathrm{NH}_{4} \mathrm{OAc}$ buffer $(\mathrm{pH}=6.5)$ and $\mathrm{MeCN}$ as eluents $(0-20 \% \mathrm{MeCN}$ over $70 \mathrm{~min}$; flow rate: $2.5 \mathrm{~mL}$; UV detection: $260 \mathrm{~nm}, 310 \mathrm{~nm}$ ). To cleave the terminal DMT group the oligonucleotides were treated with $80 \%$ acetic acid for $1 \mathrm{~h}$ at $\mathrm{rt}$. After removal of the solvent, the residue was redissolved in $\mathrm{H}_{2} \mathrm{O}$ and the emerging precipitate was removed. The oligonucleotides were lyophilized and quantified by their absorbance in $\mathrm{H}_{2} \mathrm{O}$ at $260 \mathrm{~nm}$ on a Varian Cary 100 spectrometer, including $\varepsilon_{260}=56200 \mathrm{M}^{-1} \mathrm{~cm}^{-1}$ for modification $\mathbf{S}$ (Scheme 3). dsDNA1 was formed by heating to $90{ }^{\circ} \mathrm{C}(10 \mathrm{~min})$ followed by slow cooling to rt. MALDI-MS DNA1 $\mathrm{m} / \mathrm{z}(\%)$ : $5898.9(100)[\mathrm{M}+\mathrm{DMT}]^{-}, 5597.3(99)[\mathrm{M}]^{-}, 2949.2(21)[\mathrm{M}+$ $\mathrm{DMT}^{-} / 2,2797.7$ (20) $[\mathrm{M}]^{2-} / 2$; DNA2 $\mathrm{m} / \mathrm{z}$ (\%): 5950.0 (100) $\left[\mathrm{M}+\mathrm{DMT}^{-}, 5647.9(38)[\mathrm{M}]^{-}, 2974.6(17)\left[\mathrm{M}+\mathrm{DMT}^{2-} / 2\right.\right.$, 2823.6 (7) $[\mathrm{M}]^{2-} / 2$; DNA3 m/z (\%): 5869.0 (100) [M + DMT] $]^{-}$, $5666.8(58)[\mathrm{M}]^{-}, 2944.4(12)\left[\mathrm{M}+\mathrm{DMT}^{2-} / 2,2782.6(12)\right.$ $[\mathrm{M}]^{2-} / 2$; DNA4 m/z (\%): 5919.9 (100) [M + DMT $]^{-}, 5617.7$ (34) $[\mathrm{M}]^{-}, 2957.7$ (25) $[\mathrm{M}+\mathrm{DMT}]^{2-} / 2,2808.9$ (6) $[\mathrm{M}]^{2-} / 2$. The UV-vis absorption spectra of sSDNA1-ssDNA4 are shown in Figure 3.

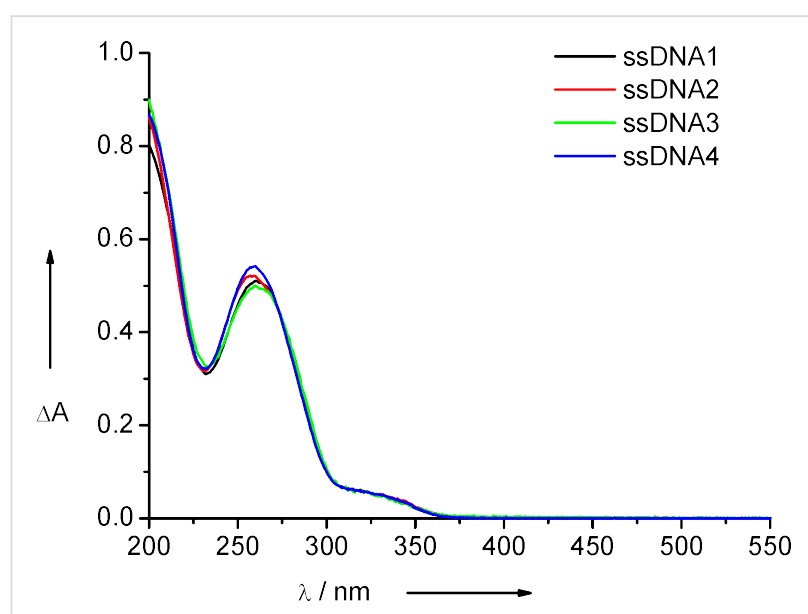

Figure 3: UV-vis absorption spectra of ssDNA1-ssDNA4 $(2.5 \mu \mathrm{M}$ in $50 \mathrm{mM} \mathrm{Na}-\mathrm{Pi}$ buffer, $\mathrm{pH}$ 7, $250 \mathrm{mM} \mathrm{NaCl}$, rt).

\section{Acknowledgements}

Financial support by the Deutsche Forschungsgemeinschaft, the University of Regensburg and the Karlsruhe Institute of Technology (KIT) is gratefully acknowledged.

\section{References}

1. Malinovskii, V. L.; Wenger, D.; Häner, R. Chem. Soc. Rev. 2010, 39, 410-422. doi:10.1039/b910030j

2. Ruiz-Carretero, A.; Janssen, P. G. A.; Kaeser, A.; Schenning, A. P. H. J. Chem. Commun. 2011, 47, 4340-4347. doi:10.1039/c0cc05155a

See review and references therein

3. Bandy, T. J.; Brewer, A.; Burns, J. R.; Marth, G.; Nguyen, T.; Stulz, E. Chem. Soc. Rev. 2011, 40, 138-148. doi:10.1039/b820255a See review and references therein.

4. Varghese, R.; Wagenknecht, H.-A. Chem. Commun. 2009, 2615-2624. doi:10.1039/b821728a

See review and references therein

5. Raymo, F. M.; Tomasulo, M. Chem.-Eur. J. 2006, 12, 3186-3193. doi:10.1002/chem.200501178 See review and references therein.

6. Cusido, J.; Deniz, E.; Raymo, F. M. Eur. J. Org. Chem. 2009, 2031-2045. doi:10.1002/ejoc.200801244

See review and references therein.

7. Pischel, U. Angew. Chem., Int. Ed. 2007, 46, 4026-4040. doi:10.1002/anie.200603990

See review and references therein.

8. Szaciłowski, K. Chem. Rev. 2008, 108, 3481-3548. doi:10.1021/cr068403q

See review and references therein

9. Renner, C.; Moroder, L. ChemBioChem 2006, 7, 868-878. doi:10.1002/cbic.200500531

See review and references therein.

10. Berkovic, G.; Krongauz, V.; Weiss, V. Chem. Rev. 2000, 100, 1741-1754. doi:10.1021/cr9800715

See review and references therein.

11. Irie, M. Chem. Rev. 2000, 100, 1685-1716. doi:10.1021/cr980069d See review and references therein.

12. Mayer, G.; Heckel, A. Angew. Chem., Int. Ed. 2006, 45, 4900-4921. doi:10.1002/anie.200600387

See review and references therein.

13. Fehrentz, T.; Schönberger, M.; Trauner, D. Angew. Chem., Int. Ed. 2011, 50, 12156-12182. doi:10.1002/anie.201103236 See review and references therein.

14. Asanuma, H.; Liang, X.; Yoshida, T.; Komiyama, M. ChemBioChem 2001, 2, 39-44. doi:10.1002/1439-7633(20010105)2:1<39::AID-CBIC39>3.0.CO;2-E

15. Nishioka, H.; Liang, X.; Kashida, H.; Asanuma, H. Chem. Commun. 2007, 4354-4356. doi:10.1039/b708952j

16. Liang, X.; Takenaka, N.; Nishioka, H.; Asanuma, H. Chem.-Asian J. 2008, 3, 553-560. doi:10.1002/asia.200700384

17. Nishioka, H.; Liang, X.; Asanuma, H. Chem.-Eur. J. 2010, 16, 2054-2062. doi:10.1002/chem.200902789

18. Yamazawa, A.; Liang, X.; Asanuma, H.; Komiyama, M. Angew. Chem., Int. Ed. 2000, 39, 2356-2357. doi:10.1002/1521-3773(20000703)39:13<2356::AID-ANIE2356>3.0.CO ;2-9

19. Liang, X.; Asanuma, H.; Komiyama, M. J. Am. Chem. Soc. 2002, 124, 1877-1883. doi:10.1021/ja011988f

20. Liang, X.; Nishioka, H.; Takenaka, N.; Asanuma, H. ChemBioChem 2008, 9, 702-705. doi:10.1002/cbic.200700649

21. Nishioka, H.; Liang, X.; Kato, T.; Asanuma, H. Angew. Chem., Int. Ed. 2012, 51, 1165-1168. doi:10.1002/anie.201106093

22. Sakata, T.; Yan, Y.; Marriott, G. J. Org. Chem. 2005, 70, 2009-2013. doi:10.1021/jo048207o 
23. Young, D. D.; Deiters, A. ChemBioChem 2008, 9, 1225-1228. doi:10.1002/cbic.200800051

24. Andersson, J.; Li, S.; Lincoln, P.; Andréasson, J. J. Am. Chem. Soc. 2008, 130, 11836-11837. doi:10.1021/ja801968f

25. Hammarson, M.; Andersson, J.; Li, S.; Lincoln, P.; Andréasson, J. Chem. Commun. 2010, 46, 7130-7132. doi:10.1039/c0cc01682a

26. Asanuma, H.; Shirasuka, K.; Yoshida, T.; Takarada, T.; Liang, X.; Komiyama, M. Chem. Lett. 2001, 30, 108-109. doi:10.1246/cl.2001.108

27. Zhang, P.; Meng, J. B.; Matsuura, T.; Wang, Y. M. Chin. Chem. Lett. 2002, 13, 299-302.

28. Beyer, C.; Wagenknecht, H.-A. J. Org. Chem. 2010, 75, 2752-2755. doi:10.1021/jo100309r

29. Beyer, C.; Wagenknecht, H.-A. Synlett 2010, 1371-1376. doi:10.1055/s-0029-1219924

30. Barrois, S.; Beyer, C.; Wagenknecht, H.-A. Synlett 2012, 23, 711-716. doi:10.1055/s-0031-1290599

31. Stafforst, T.; Hilvert, D. Chem. Commun. 2009, 3, 287-288. doi:10.1039/b818050d

32. Vomasta, D.; Högner, C.; Branda, N. R.; König, B Angew. Chem., Int. Ed. 2008, 47, 7644-7647. doi:10.1002/anie.200802242

33. Mammana, A.; Carroll, G. T.; Areephong, J.; Feringa, B. L. J. Phys. Chem. B 2011, 115, 11581-11587. doi:10.1021/jp205893y

34. Singer, M.; Jäschke, A. J. Am. Chem. Soc. 2010, 132, 8372-8377. doi:10.1021/ja1024782

35. Ranasinghe, R. T.; Brown, T. Chem. Commun. 2005, 5487-5502. doi:10.1039/b509522k

36. Waggoner, A. Curr. Opin. Chem. Biol. 2006, 10, 62-66. doi:10.1016/j.cbpa.2006.01.005

37. Cobb, A. J. A. Org. Biomol. Chem. 2007, 5, 3260-3275. doi:10.1039/b709797m

38. Wang, Y.; Haze, O.; Dinnocenzo, J. P.; Farid, S.; Farid, R. S.; Gould, I. R. J. Org. Chem. 2007, 72, 6970-6981. doi:10.1021/jo071157d

39. Raytchev, M.; Mayer, E.; Amann, N.; Wagenknecht, H.-A.; Fiebig, T. ChemPhysChem 2004, 5, 706-712. doi:10.1002/cphc.200301205

40. Sinkeldam, R. W.; Greco, N. J.; Tor, Y. Chem. Rev. 2010, 110, 2579-2619. doi:10.1021/cr900301e See review and references therein

41. Sindbert, S.; Kalinin, S.; Nguyen, H.; Kienzler, A.; Clima, L.; Bannwarth, W.; Appel, B.; Müller, S.; Seidel, C. A. M. J. Am. Chem. Soc. 2011, 133, 2463-2480. doi:10.1021/ja105725e

42. Kool, E. T. Annu. Rev. Biochem. 2002, 71, 191-219. doi:10.1146/annurev.biochem.71.110601.135453

43. Henry, A. A.; Romesberg, F. E. Curr. Opin. Biotechnol. 2005, 16, 370-377. doi:10.1016/j.copbio.2005.06.008

44. Rist, M.; Amann, N.; Wagenknecht, H.-A. Eur. J. Org. Chem. 2003, 2498-2504. doi:10.1002/ejoc.200300125

45. Wagner, C.; Rist, M.; Mayer-Enthart, E.; Wagenknecht, H.-A. Org. Biomol. Chem. 2005, 3, 2062-2063. doi:10.1039/b504079e

46. Ehrenschwender, T.; Wagenknecht, H.-A. Synthesis 2008, 3657-3662. doi:10.1055/s-0028-1083206

47. Varghese, R.; Wagenknecht, H.-A. Chem.-Eur. J. 2009, 15, 9307-9310. doi:10.1002/chem.200901147

48. Varghese, R.; Wagenknecht, H.-A. Chem.-Eur. J. 2010, 16, 9040-9046. doi:10.1002/chem.201001136

49. Wanninger-Weiß, C.; Di Pasquale, F.; Ehrenschwender, T.; Marx, A.; Wagenknecht, H.-A. Chem. Commun. 2008, 1443-1445. doi:10.1039/B718002K
50. Staiger, N.; Marx, A. ChemBioChem 2010, 11, 1963-1966. doi:10.1002/cbic. 201000384

51. Sonogashira, K. J. Organomet. Chem. 2002, 653, 46-49. doi:10.1016/S0022-328X(02)01158-0

\section{License and Terms}

This is an Open Access article under the terms of the Creative Commons Attribution License

(http://creativecommons.org/licenses/by/2.0), which permits unrestricted use, distribution, and reproduction in any medium, provided the original work is properly cited.

The license is subject to the Beilstein Journal of Organic Chemistry terms and conditions:

(http://www.beilstein-journals.org/bjoc)

The definitive version of this article is the electronic one which can be found at: doi: $10.3762 /$ bjoc. 8.103 